Copyright $\odot$ SAGE Publications 2007 (Los Angeles, London, New Delhi and Signapore) 1468-7968

Vol 7(3): 445-474;080237

DOI:10.1177/1468796807080237

http://etn.sagepub.com

\title{
The school careers of ethnic minority youth in France
}

\section{Success or disillusion?}

\author{
YAËL BRINBAUM \\ University of Burgundy - IREDU and Maurice Halbwachs Center, France

\section{HECTOR CEBOLLA-BOADO} \\ Nuffield College, University of Oxford and CEACS-Juan March Institute
}

\begin{abstract}
This article explores the educational performance and careers of the children of immigrant families and those of French natives in secondary schooling in France. Using a rich longitudinal dataset (the 1995 Panel of the Ministry of Education), we compare the parents' educational expectations with the school careers of their children. We identify higher educational expectations among immigrant parents than among natives from a similar social background. Although immigrant students begin the collège with a poorer school performance than native students, they tend to shorten this distance with the simple passage of time. Besides, most of this disadvantage is explained by class-related factors. Among the working class, there are few differences in the educational careers of children of immigrants and those of Frenchborn children in upper secondary education. Nonetheless, students from a North African ancestry seem to be less able to materialize their aspirations than the descendants of Portuguese immigrants, and thus express more frequently their dissatisfaction with their orientation in the vocational or technological track.
\end{abstract}

KEYWORDS • aspirations $\bullet$ educational careers $\bullet$ grades $\bullet$ North African immigrants Portuguese immigrants $\bullet$ second generation $\bullet$ secondary school

\section{INTRODUCTION}

France has been an immigration country since the 19th century (Noiriel, 1988), but ever since the end of the Second World War, it has been one of 
the main European destinations for immigrants. As a result, a significant proportion of its own citizens have foreign ancestry. Tribalat (2004) estimates that the number of French-born citizens and residents from a foreign origin reached 13.5 million by the end of the last decade, a figure that represents between one-fourth and one-fifth of the whole French population. It is in this context that a study of the educational attainment of second-generation immigrants in France gains huge importance.

Despite the centrality of this research topic for French society and its social cohesion, there has been an intense normative debate on the legitimacy of studying the socioeconomic stratification of second-generation immigrants (that is French-born citizens from foreign-born parents) who should be considered as French citizens. As a consequence, quantitative research on the status attainment of the immigrant population has been constrained by the lack of empirical data and public support - the loi Informatique et libertés passed in 1985 prevented researchers from asking in public surveys about ethnicity and country of birth. This restriction was the result of an old Republican trauma from the times of the Vichy Regime. Ever since then, the differentiation of the French population on the basis of ethnicity has been understood as contradicting the Republican principle of equality.

The impossibility of building precise categories and relevant variables for the study of immigration in France is partly responsible for the lack of consensus in the empirical literature on the educational attainment of immigrants in France. In the 1960s and 1970s, some sociological studies concluded that immigrants were not worse off than natives after controlling for class of origin (Clerc, 1964; Courgeau, 1973; Gratiot Alphandéry and Lambiot, 1973). In the early 1980s, some authors confirmed these conclusions (SIGES, 1984), while others suggested that immigrant students experienced some disadvantage in the number of years that they repeated in school (SEIS, 1980; Mondon, 1984). Other studies even argued that, controlling for family socioeconomic background, they obtained better school results than natives (SIGES, 1978) and even more successful school careers (Mondon, 1984). In the early 1990s, a number of empirical studies confirmed that, controlling for class, the gap between the educational attainment of immigrants and natives was not significant (Boulot and BoyzonFradet, 1988; Mallet and Bousta, 1988; Duru-Bellat and Mingat, 1990), although Thélot and Vallet (1994) suggested that immigrants were slightly but significantly disadvantaged with respect to natives. Finally, Vallet and Caille (1996) published the most comprehensive and systematic analysis of the educational attainment of the immigrant population in France, using the 1989 Panel of Students in Secondary Education (see the Appendix for an explanation of the panel of students). There, the authors concluded that the school performance of immigrants and natives was similar, and that the former group followed more successful and ambitious school careers than 
the latter. Vallet and Caille (1996) also referred to the higher educational expectations and aspirations among immigrant families as the reason for their success, something that has been widely documented in the AngloSaxon literature as a potential explanation for their good educational results (Kao and Tienda, 1995 for instance). A further study of immigrant families' expectations has confirmed this argument, although stressing differences between ethnic groups according to their geographical origin (Brinbaum, 2002).

The 1989 Panel of Students in Secondary Education used by Vallet and Caille (1996) did not allow the use of proper immigration or ethnic categories. Instead, the authors used several proxies to build an index of immigrant status and ethnicity. Fortunately, the recently available 1995 Panel produced by the French Ministry of National Education includes for the first time in a national panel a list of variables, including the students' and their parents' countries of birth and nationality, enabling one to build a clear-cut set of immigrant and ethnic categories. In addition, a subsample of the students was interviewed in 2002 to collect information about their school careers and their educational expectations. Through the exploitation of this new dataset, our article helps to consolidate former conclusions and represents a good opportunity to contribute to the large specialized literature.

The debate around the magnitude and causes of the educational success of the children of immigrants is still open in France. Our objective is to describe the educational experience of immigrant children throughout secondary schooling and to quantify potential differentials in the educational attainment of the children of immigrant and French-born families. To do so, we use several indicators: school performance in lower secondary school and school careers in upper secondary and the families' expectations regarding their children's education. By considering objective and subjective aspects of the process (educational expectations and ambitions, tracks chosen and the perception of the educational experience by the children themselves), we try to improve the understanding of the mechanisms that determine the educational attainment of the children of immigrant and French-born families.

Because of the constraints imposed by the sample sizes, we decided to restrict our analyses to the children of Portuguese and North African (Algerian, Moroccan and Tunisian) parents, the largest immigrant groups in France. As we can see from the 1999 Census (see Figure 1), the Algerians represent the largest community, followed very closely by the Portuguese. Moroccans and Tunisians are the third and sixth largest immigrant groups in the country. The dataset and the sample sizes are described in the Appendix. 


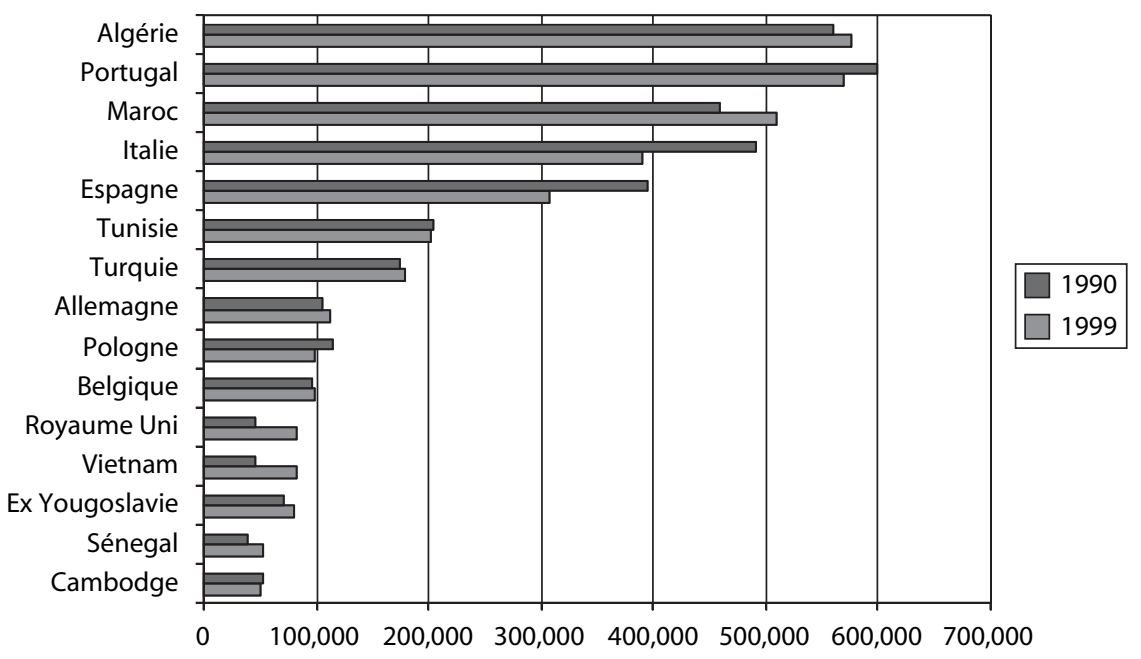

Figure 1 Immigrants in France according to Country of Birth in 1990 and 1999

Source: INSEE, 1990, 1999.

\section{THE FRENCH EDUCATIONAL SYSTEM}

The French educational system is organized in three levels (see Figure 2). The first level includes the pre-elementary schools (écoles maternelles), which provide education before compulsory schooling, and the primary schools for children from the age of six. Secondary education is divided into two cycles:

- The lower secondary education in the college from the sixth to the third grades, which leads in four years to the brevet (BEPC), a general certificate, awarded on the basis of marks achieved in the national examination and of the results during the school year.

- The upper secondary education in the lycées from the second grade to the Terminale, which leads to the baccalauréat. This diploma gives access to higher education.

The collège, known as the 'collège unique' since 1975, represents a comprehensive type of lower secondary school for all pupils. Its final year - the third grade - is a key moment in the educational schedule because selection to upper non-compulsory education happens at this stage. The system offers two alternatives:

- the academic track leads to a general or technological baccalauréat;

- the vocational track, the first year of preparation for a vocational 




Figure 2 The French educational system Source: OECD (1995), Education at a glance, OECD, Paris, pp. 273-5.

certificate (BEP - brevet d'études professionnelles - or CAP certificat d'aptitude professionnelle). After obtaining this first vocational qualification, students can leave the school system or proceed towards the vocational baccalauréat.

In the mid 1980s, the Ministry of Education claimed that the system pushed some ' $80 \%$ of each generation to the Baccalauréat'. The vocational baccalauréat was created (in 1985), especially for working-class students who used to obtain lower vocational diplomas such as the CAP or BEP. However, the system remains highly selective. The general baccalauréat keeps its pre-eminence in terms of status and opens the clearest way to tertiary education. The technological baccalauréat is less valued but allows students to stay in the academic track and it provides access to University. ${ }^{1}$ 
In contrast, the lower secondary vocational CAP and BEP allow people to find a job quite rapidly and without further studies, depending on the individual training.

\section{THE HIGHER ASPIRATIONS OF THE IMMIGRANT POPULATION IN SECONDARY SCHOOLING ${ }^{2}$}

In France, the educational expectations of families have increased as a consequence of educational expansion and of educational policies that have democratized access to secondary schooling. Nowadays, most French families perceive that the baccalaureate is the minimum educational level that they expect for their offspring. It could be argued that this is the general norm, even if some visible differences continue to differentiate affluent and working-class families (Beaud et Pialoux, 1999). However, the differences between immigrant and French native families' aspirations are less known.

The 1995 Panel of Students asked all parents about their preferred secondary education diploma at the end of lower secondary schooling (1998). Some 47 percent of the parents reported that they preferred the general baccalauréat, while the technological baccalauréat was a preferred option for only 4.5 percent of the interviewed parents. Only a quarter of the families were more inclined towards a vocational diploma (CAP, BEP or vocational baccalauréat). At the same time, parental expectations, and perceptions of the social prestige of each track, ranked according to family socioeconomic background. We can broadly say that higher class families overwhelmingly preferred the general baccalauréat (it was the preferred option in more than 80 percent of the cases), while only a little less than one half of middle-class parents did so and barely one-third of working class parents $(30 \%)$. Parents from this latter group were more likely to prefer CAP, BEP or a vocational baccalauréat. ${ }^{3}$

It is important to highlight differences between immigrant and nonimmigrant families from similar socioeconomic backgrounds. Immigrant working-class families were more likely to prefer a general baccalauréat than their non-immigrant counterparts. Within the immigrant population we can also speak about certain ethnic differentials: the Portuguese families tended to behave just as French families do (they preferred the academic tracks in 28 percent and 25 percent of the cases: see Table A3), while North Africans were more likely to prefer a general track and even tertiary education for their children (in some $47 \%$ of cases).

Those outcomes are confirmed by modelling (Table 1) parents' educational aspirations for their children. ${ }^{4}$ Again, social background appears as an important influence on the hopes for a general baccalauréat, 
but parental education also plays an important role. Moreover, irrespective of their social characteristics or their educational level, North Africans express high educational aspirations for the general track. If school performance reduces significantly this aspiration, North Africans persevere despite weaker school results. While the working-class families persevere only if the school level of their children is sufficiently high to ensure their success (Boudon, 1974; Duru-Bellat et al., 1993), the North African families maintain their efforts without taking into account the actual performances of their children.

The choice of a technological track can become an alternative when school problems are encountered. It is then a question for them to ensure the continuation of schooling via the vocational baccalauréat and the possibility of accessing higher education. ${ }^{5}$

Parental aspirations were strongly linked to the perceived utility of the diploma in the labour market. ${ }^{6}$ The Portuguese families did not seem to value higher education diplomas as much as other groups did, and this is why Portuguese parents estimated that obtaining a vocational certificate was an acceptable success. Interestingly, many Portuguese families failed to answer the question about this, something that might reveal a lack of knowledge about the functioning of the French school system. In contrast, North African parents from all social origins emphasized the importance attached to the general baccalauréat. For North Africans, schooling and higher diplomas were trusted as a means of ensuring upward social mobility. This also indicates that parental expectations regarding their children's educational future are not built solely on the basis of their school results, unlike native French from the same social background.

These different perceptions and the optimism among immigrant families - especially among North Africans - are of key importance. ${ }^{7}$ The reason is that the preferences expressed by the families at the end of lower secondary schooling are taken into account when deciding the track that the student is to follow in upper secondary education. ${ }^{8}$ This is why some authors have criticized the way students are selected, since consideration of family preferences can amplify the negative effect of familial constraints, leading to stronger class differentials in access to upper secondary schooling (DuruBellat and Kieffer, 2000; Merle, 2002).

The following section explores the differences in the results and the school careers of immigrants and the children of French-born families. In particular, we ask whether the educational outcomes of the immigrant students match the level of their families' aspirations and expectations. 


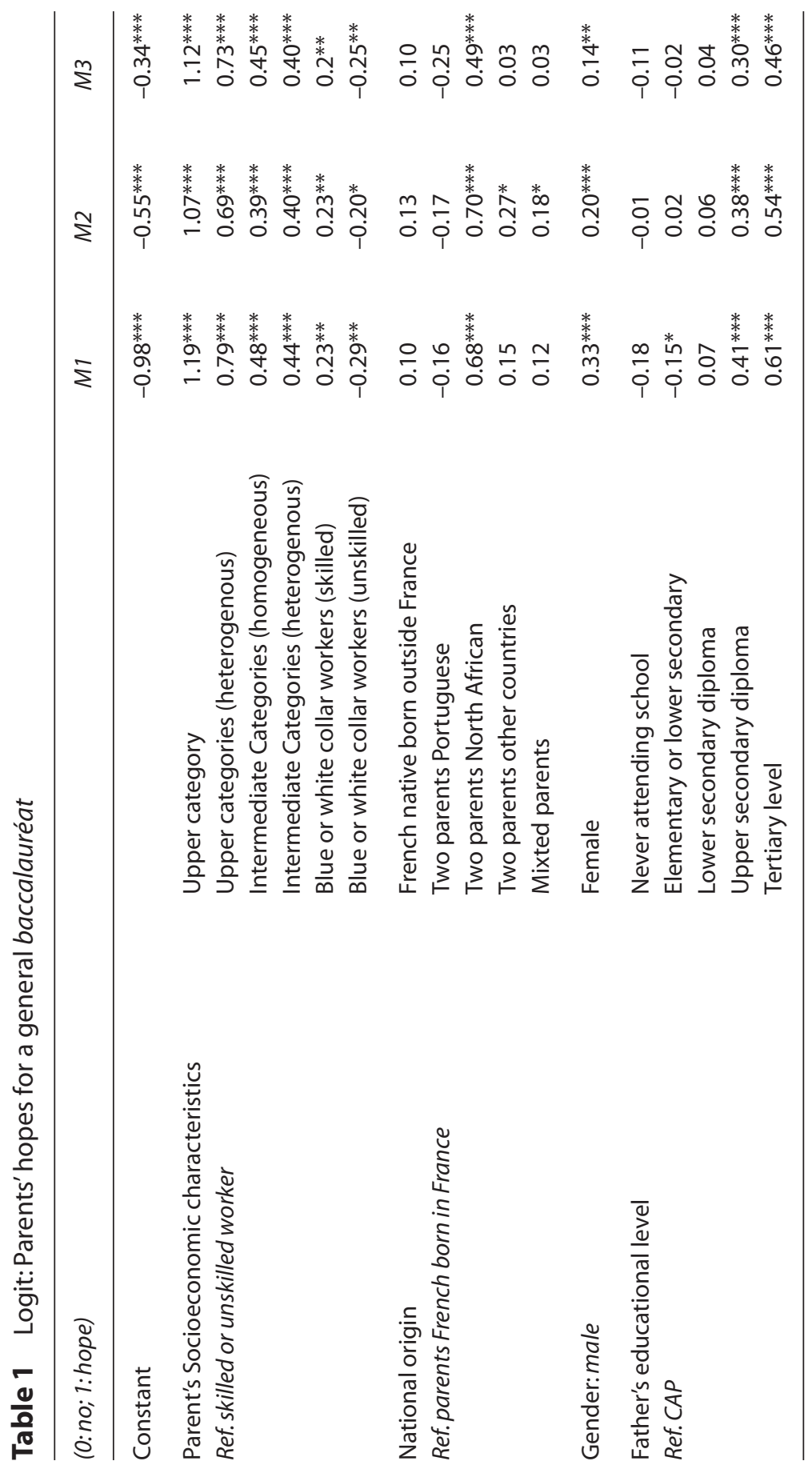




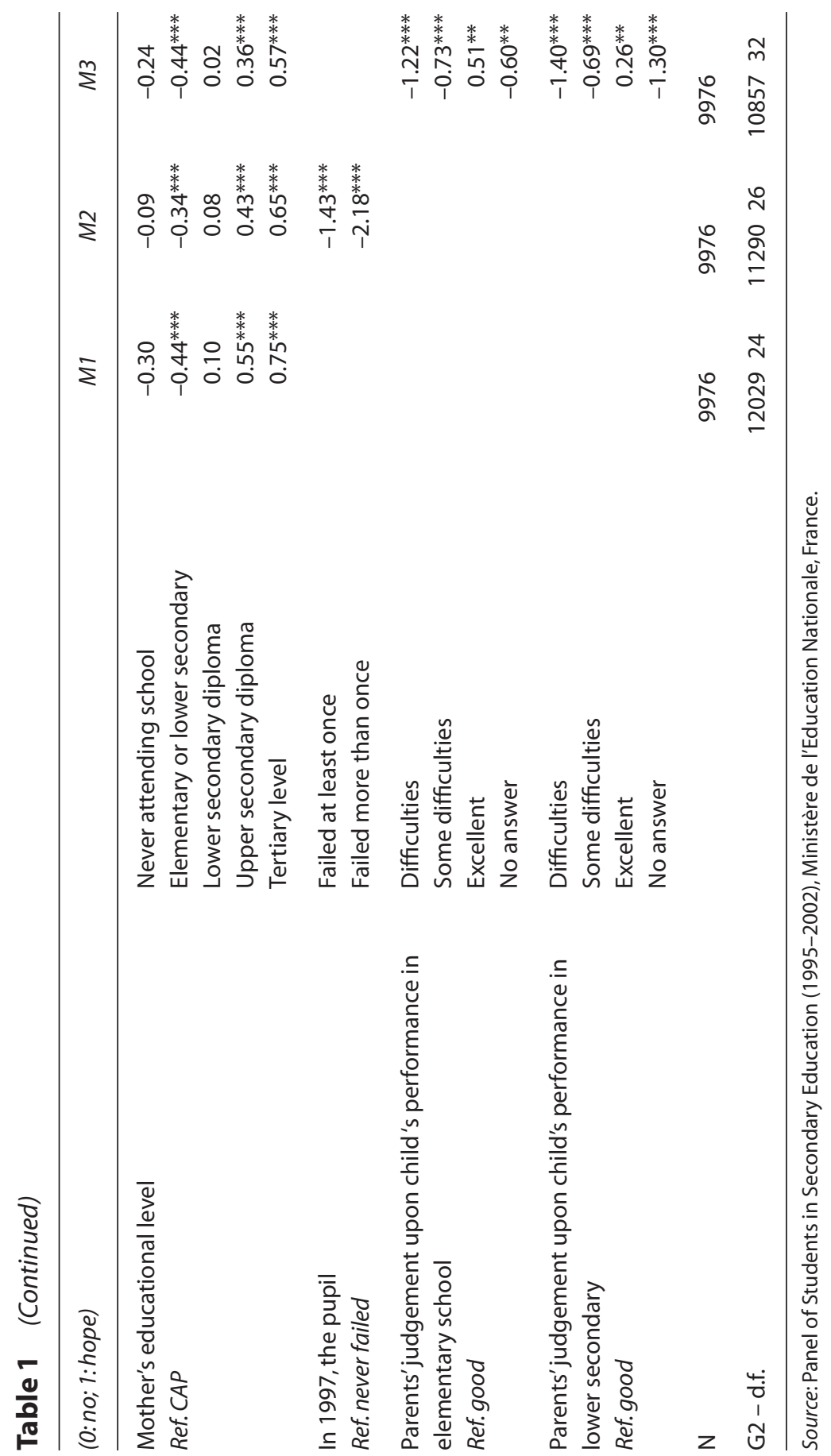




\section{EDUCATIONAL OUTCOMES: GRADES AND TRACKS IN UPPER SECONDARY SCHOOLING}

\section{School performance: Grades in mathematics and French language (1995 and 1998)}

French research on educational attainment in secondary schooling normally uses grades in mathematics and French as useful proxies for school performance. The 1995 panel allows investigation of the results obtained by students in these two subjects at their entrance into lower secondary schooling (1995) and the average grade reached in the brevet des colleges in 1998 at the end of lower secondary schooling. These variables have been harmonized so that the four of them range from 0 to 100. Figures 3 and 4 show the results obtained by each group in 1995 and 1998 in mathematics. We have divided the range of grades into three (the lowest ranging from 0 to 33 , the next from 34 to 66 and the upper from 67 to 100). Accordingly, each bar is divided into three parts, indicating the percentage distribution of students across these grades.

If we focus on the grades in maths, we can see that the differentials in grades are bigger at the beginning of the period under observation (1995) than three years later (1998). In the 'evaluation' exams conducted in 1995, some 55.7 percent of the French children obtained grades of 67 and above, while the percentage for the North Africans only reached 24.3. In contrast, the equivalent figures for 1998 are 26.8 percent and 12.6 percent respectively. It is also evident that, after three years of attendance in lower secondary education, all the groups have fewer students in the 67-100 range than in 1995 and more in the intermediate third.

If we observe the grades in French (Figures 5 and 6), we obtain a somewhat similar picture. The differences between the groups are far more evident in 1995 than in 1998. While in 1995 some 62 percent of the children of French-ancestry families got scores in the range 67-100, only 34 percent of the children with both parents from North Africa did so. Meanwhile, in 1998, only 19.6 percent of the French were in the highest third compared with 9.6 percent of the North Africans. In 1998, the children of Frenchancestry families were still the most successful group, but their advantage in comparison to the other groups was smaller than in 1995.

Let us now see if these differences can be explained by multivariate analyses. The Tables 2 and 3 present the results of stepwise regression analyses for the grades in mathematics at the beginning of lower secondary schooling (1995) and at the end of this period (1998) respectively. For the sake of simplicity, we omit the analysis where the grades in French are the dependent variable. The conclusions that can be drawn from this second set of models confirm what we say here about mathematics. ${ }^{9}$

The regression estimates before adding any controls (model 1) do not 


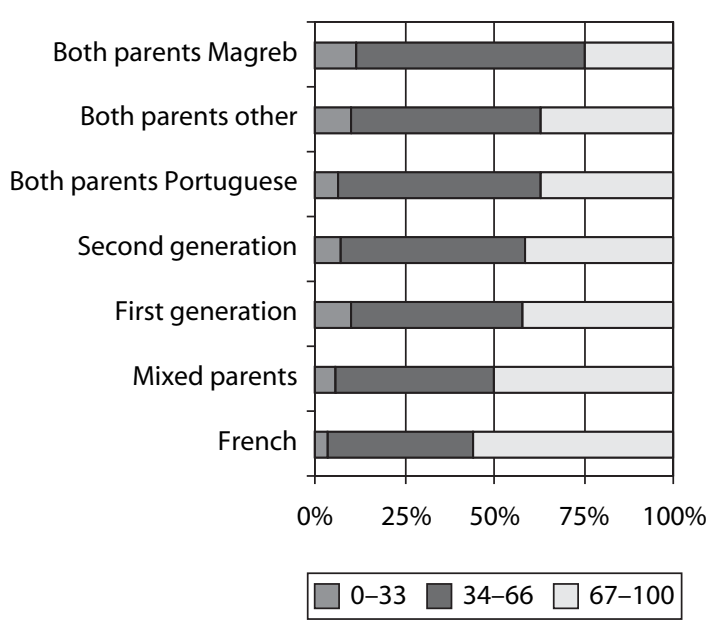

Figure 3 Mathematics in 1995

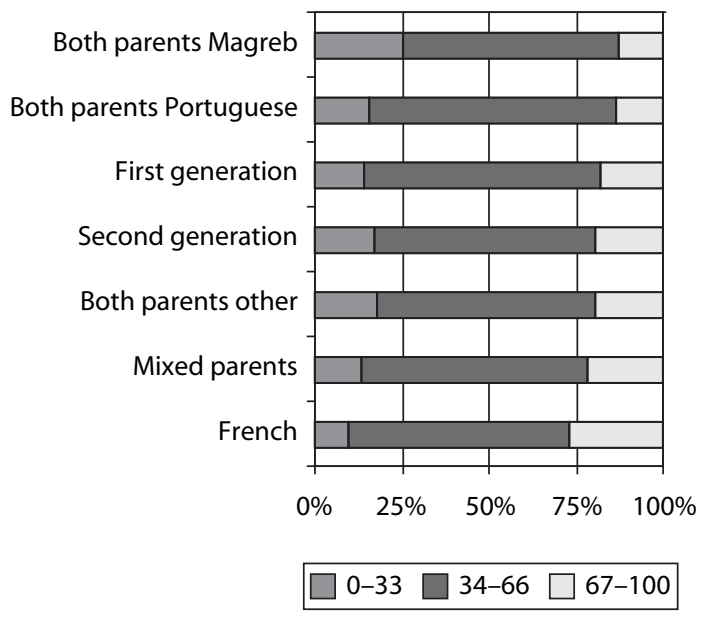

Figure 4 Mathematics in 1998

show any statistically significant difference between second-generation immigrant students and natives of French ancestry (the reference category). The same is valid for immigrant students born abroad. In these two cases, the estimates are positive under the current model specification. The model indicates that the source of disadvantage of the immigrant population is captured by the negative coefficients of the ethnic categories (both parents from North Africa, both parents born in Portugal, and those born in other countries). The highest disadvantage affects the children of parents born in 


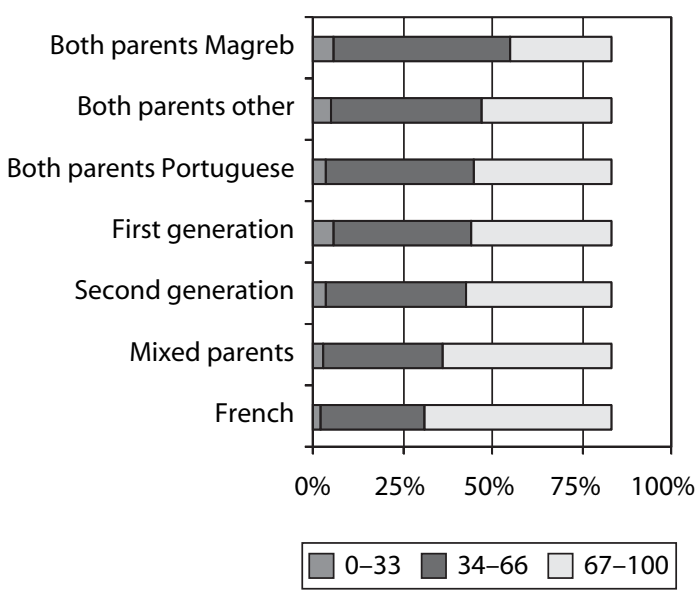

Figure 5 French in 1995

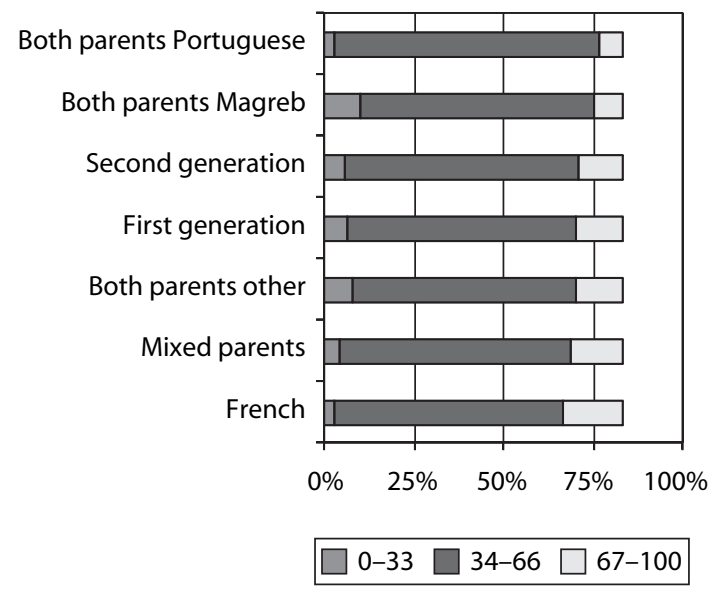

Figure 6 French in 1998

Algeria, Morocco and Tunisia. The interactions between these two variables and the students' immigration status (student born abroad and second generation) are not statistically significant, indicating that the North African disadvantage is similar both in the first and in the second generation.

The second model specification introduces the father's and the mother's highest level of education and the student's sex. The introduction of the level of parental education has the expected effect: a higher level of education is associated with higher grades. Father's education seems prima facie to work as a stronger determinant of school success as measured by grades in mathematics at the beginning of lower secondary schooling. ${ }^{10}$ 
Table 2 OLS regression of grades in mathematics at the beginning of college (1995)

\begin{tabular}{lcccc}
\hline & Model 1 & \multicolumn{3}{c}{ Model 2 } \\
\hline Student born abroad & 3.675 & $(2.04)$ & -0.539 & $(2.06)$ \\
Second generation & 3.367 & $(2.30)$ & 1.495 & $(2.29)$ \\
Both parents: & & & & \\
$\quad$ Maghreb & $-16.271^{* * * *}$ & $(2.33)$ & -4.354 & $(2.36)$ \\
$\quad$ Portugal & $-10.494^{* * * *}$ & $(2.56)$ & 1.195 & $(2.61)$ \\
$\quad$ Other countries & $-12.245^{* * *}$ & $(2.36)$ & -4.017 & $(2.32)$ \\
Mixed parents & -3.889 & $(2.32)$ & -2.206 & $(2.31)$ \\
Father's education & & & $2.177^{* * *}$ & $(0.11)$ \\
Mother's education & & & $2.729^{* * *}$ & $(0.11)$ \\
Sex & & & 0.256 & $(0.30)$ \\
Constant & $67.201^{* * *}$ & $(0.18)$ & $48.422^{* * *}$ & $(0.52)$ \\
$N$ & 11,009 & & 11,009 & \\
$F$ & $74.11^{* * *}$ & & $278.73^{* * *}$ & \\
$R^{2}$ & 0.041 & & 0.201 & \\
\hline
\end{tabular}

$\beta$ and standard errors; ${ }^{*} p<.05 ; * * 0<.01 ;{ }^{* * *} p<.001$.

Table 3 OLS regression of grades in mathematics in brevet des collèges (1997-98)

\begin{tabular}{lcccc}
\hline & \multicolumn{3}{c}{ Model 1 } & \multicolumn{3}{c}{ Model 2} \\
\hline Student born abroad & 0.197 & $(2.14)$ & -3.015 & $(2.27)$ \\
Second generation & -1.807 & $(2.51)$ & -2.481 & $(2.60)$ \\
Both parents: & & & & \\
$\quad$ Maghreb & $-8.451^{* *}$ & $(2.57)$ & 0.903 & $(2.68)$ \\
$\quad$ Portugal & -4.457 & $(2.92)$ & 5.137 & $(3.02)$ \\
$\quad$ Other countries & -3.387 & $(2.54)$ & 1.456 & $(2.62)$ \\
Mixed parents & 0.849 & $(2.52)$ & 0.973 & $(2.62)$ \\
Father's education & & & $2.180^{* * *}(0.13)$ \\
Mother's education & & & $1.716^{* * * *}(0.13)$ \\
Sex & & & $1.541^{* * *}$ & $(0.34)$ \\
Constant & $56.943^{* * *}$ & $(0.19)$ & $40.650^{* * *}$ & $(0.57)$ \\
$N$ & 9296 & & 9296 & \\
$F$ & $25.563^{* * *}$ & & $132.892^{* * *}$ & \\
$R^{2}$ & 0.019 & & 0.118 & \\
\hline
\end{tabular}

$\beta$ and standard errors; ${ }^{*} p<.05 ;{ }^{* *} p<.01 ;{ }^{* * *} p<.001$. 
Girls obtained significantly better results than boys in both subjects. ${ }^{11}$ The most important conclusion drawn from these models is that the negative effects of the ethnic coefficients - North African, Portuguese and other countries - that were highly significant under the previous model specification are clearly reduced after controlling for parental education. The negative sign is even reversed in the case of the Portuguese families. The North African estimate and that for other countries keep the negative sign, but more importantly these estimates are not significantly different from the reference category in model 2 for the grades in maths and are also close to non-significance in the equivalent model where French is the dependent variable.

Let us now turn to the situation at the end of lower secondary schooling, using the average score in mathematics and French as given by the brevet des collèges. Here the results are presented following the protocol established in the previous table.

The first model (model 1) depicts a similar scenario to the one described for 1995. There are no significant differences between first- and secondgeneration immigrant students in comparison with the reference category (the children of French ancestry). There are some traces of negative estimates associated with the country where the parents were born, but in terms of statistical significance this is restricted to the children of North African origin. The most important difference between 1995 and 1998 is that in this second moment of time, the ethnic estimates are considerably smaller than in the 1995 analyses.

When the model considers the level of parental education (model 2), the only significant effect associated with the immigration categories disappears. Both the father's and mother's level of education and the students' sex have the predicted sign. ${ }^{12}$ Thus, independently of whether we study school results at the beginning or at the end of lower secondary education, the children of immigrant parents and the children of French-ancestry families from a similar socioeconomic origin reach the same levels of success. Is this equality in school results also reflected in the school tracks followed in upper secondary schooling?

\section{SCHOOL CAREERS: SUCCESS AND DISCREPANCY BETWEEN ASPIRATIONS AND OUTCOMES}

\section{Early difficulties in elementary schools}

In France, social inequalities in education appear at the beginning of elementary education or even, as some authors argue, before then (DuruBellat, 2002); but children whose parents are immigrants encounter more 
difficulties at this stage compared to those from French-born families from a similar socioeconomic origin. They arrive at lower secondary school with an age of entry that on average is higher than that of their schoolmates. Apart from taking longer to reach elementary schooling, they begin lower secondary schooling with a poorer academic level (see Figures 3 and 5).

\section{Selection into upper secondary schooling}

Selection into upper secondary education is decided within the so-called orientation process. This selective process links compulsory and noncompulsory education and is coordinated by an institution known as the Class Council that assembles teachers and officials from the school division to decide case-by-case the track that each student is invited to follow after age 16. The process begins with an interview with the families where they are invited to express their most preferred options regarding their child's education. Together with this information, the Council uses other sources of information to evaluate the students' prospects and chances of success. Among this information, the grades obtained in the brevet des collèges, especially the scores in mathematics and French language, have substantial importance.

The track selected by the class council is our next dependent variable. Final-choice is a dummy variable set equal to 1 when the final decision taken by the class council is the academic option (seconde générale et technologique) and 0 otherwise (seconde professionnelle and certificat d'aptitude professionnelle). ${ }^{13}$

The first model in Table 4 (M1) does not show any statistically significant parameter. In spite of that, two coefficients present levels of significance that should be considered; both parents Portuguese $(p=.077)$ and both parents Maghrebian $(p=.065)$. These two estimates have a negative sign, so the model suggests that having two Portuguese or two North African parents makes the student less likely to be invited to proceed towards the more academic track. This probability reaches .53 for the children of two Maghrebi (setting the values of the other variables in the model at the overall mean) and .51 for the children of two Portuguese while it is .68 and .69 respectively in the rest of the cases.

The second model (M2) includes father's and mother's education and the student's sex. As before, these variables behave in the predicted way. Mother's education now has a larger coefficient than the father's, although the difference in the effects of the father's and the mother's highest level of education is not substantial.

The third model (M3) completes the model specification by including the average grade obtained in the brevet. It is expected that selection into upper secondary schooling is mostly driven by merit (or school results) rather than by any ascriptive source of disadvantage such as ethnicity or class of origin. 
Table 4 Logit models of track chosen in upper secondary schooling

\begin{tabular}{|c|c|c|c|}
\hline (0:vocational; 1:academic) & Model 1 & Model 2 & Model 3 \\
\hline Student born abroad & $\begin{array}{l}0.305 \\
0.33\end{array}$ & $\begin{array}{c}-0.148 \\
0.43\end{array}$ & $\begin{array}{c}-0.217 \\
0.45\end{array}$ \\
\hline Second generation & $\begin{array}{l}0.079 \\
0.36\end{array}$ & $\begin{array}{c}-0.029 \\
0.48\end{array}$ & $\begin{array}{c}-0.148 \\
0.49\end{array}$ \\
\hline \multicolumn{4}{|l|}{ Both parents: } \\
\hline Maghreb & $\begin{array}{c}-0.681 \\
0.37\end{array}$ & $\begin{array}{l}0.867 \\
0.49\end{array}$ & $\begin{array}{l}1.461^{* *} \\
0.50\end{array}$ \\
\hline Portuguese & $\begin{array}{c}-0.725 \\
0.41\end{array}$ & $\begin{array}{l}0.735 \\
0.53\end{array}$ & $\begin{array}{l}0.868 \\
0.57\end{array}$ \\
\hline Other countries & $\begin{array}{c}-0.454 \\
0.36\end{array}$ & $\begin{array}{l}0.459 \\
0.48\end{array}$ & $\begin{array}{l}0.706 \\
0.50\end{array}$ \\
\hline Mixed parents & $\begin{array}{l}0.115 \\
0.37\end{array}$ & $\begin{array}{l}0.183 \\
0.48\end{array}$ & $\begin{array}{l}0.487 \\
0.50\end{array}$ \\
\hline Father's education & & $\begin{array}{l}0.297^{* * *} \\
0.02\end{array}$ & $\begin{array}{l}0.146^{* * *} \\
0.02\end{array}$ \\
\hline Mother's education & & $\begin{array}{l}0.389^{* * *} \\
0.02\end{array}$ & $\begin{array}{l}0.210^{* * * *} \\
0.02\end{array}$ \\
\hline Sex & & $\begin{array}{l}0.630^{* * *} \\
0.05\end{array}$ & $\begin{array}{l}0.239^{* * *} \\
0.06\end{array}$ \\
\hline Mean brevet score & & & $\begin{array}{l}0.761^{* * *} \\
0.02\end{array}$ \\
\hline Constant & $\begin{array}{l}0.778^{* * *} \\
0.02\end{array}$ & $\begin{array}{l}-2.079^{* * *} \\
0.09\end{array}$ & $\begin{array}{c}-7.444^{* * *} \\
0.28\end{array}$ \\
\hline$N$ & 9038 & 9038 & 9038 \\
\hline $\mathrm{Chi}^{2}$ & 62.932 & $1382.45^{* * *}$ & $1978.06^{* * *}$ \\
\hline Pseudo $R^{2}$ & 0.006 & 0.143 & 0.4024 \\
\hline
\end{tabular}

$\beta$ and standard errors; ${ }^{*} p<.05 ;{ }^{* *} p<.01 ;{ }^{* * *} p<.001$.

This variable is revealed to be the strongest determinant of the students' likelihood of proceeding towards the academic track. After controlling for this measure of school success, being the children of two North Africans turns into a significantly positive factor, something that has been detected previously in several empirical studies on this topic (Vallet and Caille, 1996; Felouzis 2003). This means that students with North African ancestry are more likely to be invited to continue their studies in seconde générale et technologique than are children of French ancestry with similar parental 
education and brevet scores. The difference in probabilities is over 10 percent - .95 for the child of two North Africans compared with .82 for the child of two French ancestry parents.

\section{A 'bad' orientation as a source of frustration}

In 2002, the children were also asked about their educational careers and especially about their experience at school. Nineteen percent of the youngsters had the feeling that the Class Council that decided the track they should follow in upper secondary was unjust towards them, but while 17 percent of children of Portuguese families reported this feeling, 25 percent of North Africans did so. It is known that the students generally accepted the verdict, but those sharing a North African origin rather perceived it as an injustice, in particular when they were assigned to the vocational track (42\% feeling this way). This percentage was much smaller among those of French or Portuguese origin (18.6\% and 20\% respectively). The 1995 Panel also allows one to measure the discrepancy between their wishes before the orientation and the Class Council's decision: only 26 percent of the children of French-born families were in this discrepant situation, but the figures increase to 33 percent and 39 percent for the children of Portuguese and North African families respectively.

\section{School careers in secondary education}

By now we have seen that students of immigrant families do not have a worse level of school achievement than those of French-ancestry families from a similar socioeconomic background and that there are no significant differences between these two groups in the tracks that they are invited to follow in upper secondary schooling. In this section, we study their actual educational careers: where are the 1995 cohort surveyed by our Panel of Students seven years after their entrance into lower secondary education?

In spite of the general increase in the families' educational aspirations across social classes, there are noticeable differences in the school careers followed by the students according to their social origin. Educational careers are indeed largely explained by the children's social background and their parents' education, and to a certain extent this is independent of measures of school success such as whether or not that they arrive on time for the terminale class. In 2002, more than 90 percent of the 1995 cohort were still attending secondary school and a quarter of them were moving towards the general baccalauréat.

Let us now focus on the working-class families in the sample surveyed in the 1995 Panel of Students to compare the careers of the children of immigrant families and those of French-ancestry families (Figure 7).

The graph is revealing. Few students dropped out. Only 13 percent of the 


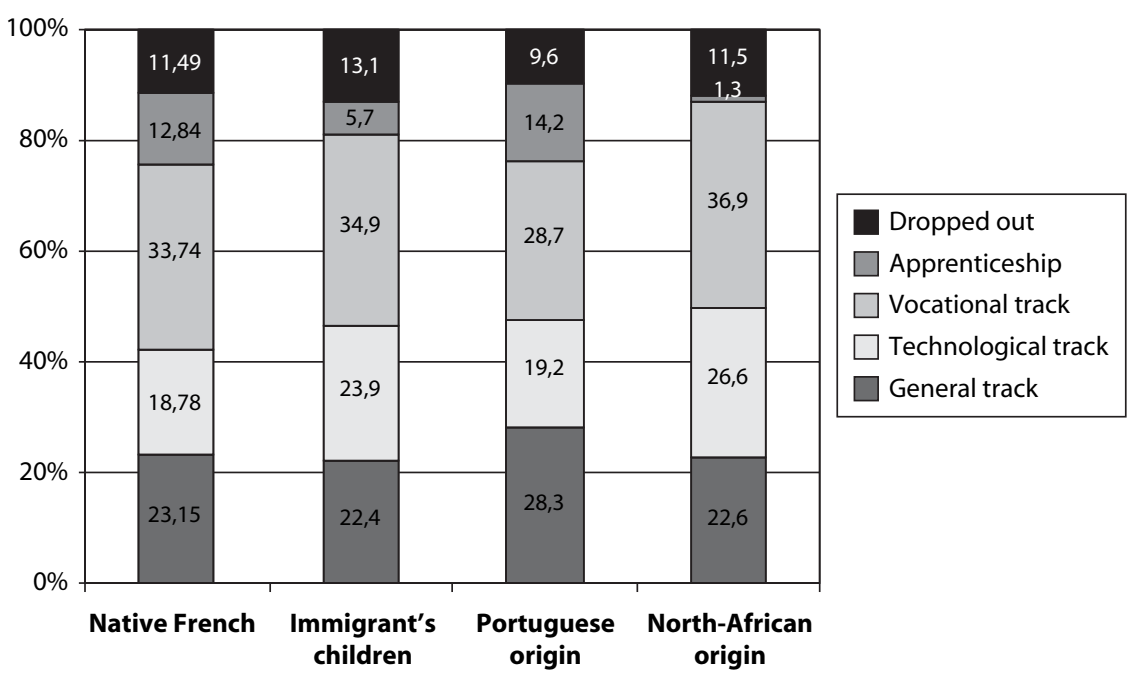

Figure 7 School situation in 2002 for lower categories (1995 cohort)

Portuguese did so and less than 12 percent of the French and North Africans. Besides this, it is important to highlight that, in spite of their average poorer performance, children from a North African origin are less represented in the less attractive tracks (vocational and apprenticeship) than are the other groups. Across categories, the largest percentage of students is found in the vocational track, and differences between children of immigrant and those of native French families are not very large. This is true for the children of immigrants irrespective of their ethnic ancestry. While 33.7 percent of the French ancestry and 36.9 percent of the children of North African families are in this option, only 28.7 percent of the Portuguese ancestry children follow the vocational track. There are also some differences in the rate of access to apprenticeship, which are traditionally more popular among students from a Portuguese origin $(14.2 \%)$ and the children of French-born families (13\%) than among North African children $(1.3 \%)$.

Overall, the children of immigrant families, and especially those from the Maghreb, are more likely to attend the academic track than the children of native French families from a similar social origin. If we merge the general and the technological baccalauréat into a single category we find that, while only 42 percent of the children of French-born families are in these tracks, more than 47 percent and 49 percent of the offspring of Portuguese and North African families take these tracks (confirming previous findings from Vallet and Caille, 1996). ${ }^{14}$ But this success must not hide the fact that, within the more attractive option general + technological baccalauréat, the 
children of immigrant families are more likely to continue in the technological track. In this respect, it is possible to speak about a certain discrepancy between the educational aspirations and real school careers followed by the children of immigrants.

How can we explain these outcomes? The school careers are linked to family social background and to the parental level of education. Immigrant families have difficulties in helping their children with their homework or more generally to guide them (Thin, 1998; Van Zanten, 2001; Brinbaum, 2002). They lack the kind of knowledge that is required to navigate the French school system and they do not have the cultural and socioeconomic resources that would allow them to adopt the strategies of the French middle class. Their poorer levels of school success - as measured by grades in this article - can proxy these difficulties while at the same time it can also explain why they are less likely to proceed towards the vocational track.

However, there are some differences in aspirations according to migration status and ethnicity - between the Portuguese and the North Africans - and therefore a lack of agreement between the educational aspirations and outcomes of some immigrant groups. However, part of the immigrant subsample never attended school or, if they did, they dropped out early. In the mean time, the French-born working class has gone at least through the period of compulsory education and only left school after failing or not being selected for further education. It is for this reason that Tribalat (1995) suggests that a direct comparison between these two populations is tricky. Among the immigrant population, the lack of formal education or their short attendance at school provokes a certain feeling of frustration towards the school system. This is particularly the case for the mothers from a North African origin who extrapolate their ambitions to their children's careers (Zéroulou, 1988), while the Portuguese mothers have nonetheless attended school even if it was only up to primary level. The pursuit of studies may also be explained as a defensive strategy against difficulties expected in the French labour market and, in particular, the high rates of unemployment experienced by North Africans and the discrimination that they would be confronted with when they look for a job (Brinbaum and Werquin, 1999). Nevertheless, their higher educational ambitions and expectations push their children towards the academic tracks despite the fact that their social origins, and especially their family resources, would tend to reduce their chances of success. ${ }^{15}$ 


\section{ASPIRATIONS FOR HIGHER EDUCATION}

In 2002, the majority of the students who were interviewed reported plans to continue studying in higher education irrespective of their geographical origin. Eighty percent of those placed in the lower track had this plan. Logically, this plan is more frequent for students attending classes in the general track - which leads to the university - but it is also high among those who are in the vocational tracks. While only 55 percent of the children of French ancestry families in the lower track expressed this plan, some 75 percent of the children of immigrants expressed such a wish. Controlling for social class and parental education, the plan to attend higher education was significantly higher among young people of foreign origin than among the children of French natives (see Table A4.). Educational aspirations are generally more ambitious among girls than among boys across both the social and the ethnic axes. Ambition decreases when the school career and the track are taken into account (see model 2 ), in particular for those who had repeated years during their schooling or who had followed the vocational track. But the difference between children of French ancestry families and the children of immigrants are even more marked when we take into account performance in maths and French in collège (evaluated by the pupils themselves in 2002). If difficulties during the school career are negatively correlated with the plan to continue studies in higher education, this affects less the plans of the second generation, whatever their geographical origin. In North African families, high educational aspirations are transmitted across generations; the technological track in particular is perceived as a possible alternative to reach higher education.

\section{CONCLUSION}

Immigrant families hold higher educational expectations regarding their children's education than French-ancestry ones from a working-class background. Within the immigrant category, there are some differences between the Portuguese families, who are more inclined towards the vocational tracks and shorter studies, and the North African families who are more likely to be in favour of longer studies in the general or more academic tracks. Nonetheless the immigrant families are not always able to materialize their ambitions into successful school careers.

After early difficulties in elementary school, the children of immigrant families perform less well on average in secondary education than the children of French natives. However this apparent disadvantage is almost 
fully explained by the unequal social stratification of immigrants and natives as measured by their parents' education. Regarding their selection for upper secondary schooling, the children of immigrant families are more likely to follow the general and technological tracks that may lead more easily to university, once we control for parental education. But their success is moderate because they are more often channelled towards the technological track rather than to the general one.

The group differentials in the educational careers followed by the students surveyed in the 1995 panel are clearly larger across socioeconomic cleavages than across the ethnic axis. Nonetheless, there are some important factors that we must highlight. There are important differences in the degree to which the initial aspirations are actually materialized. While the outcomes of the Portuguese children are more in agreement with their families' aspirations, the expectations of the North Africans are clearly higher than their actual educational achievements. This could be due to the difficulties that they experience throughout secondary education in France. Accordingly, they are less likely to be satisfied with the Class Council's decision regarding their selection into upper secondary schooling. Such discrepancy can be an important source of frustration (Ogbu, 1978; Beaud, 2002), which might then be amplified by their difficult transitions from school to the labour market.

\section{Notes}

1 There is a real vocational pathway but the orientation towards vocational or technical track does occur in France in a negative way: 'good' pupils are invited to attend the general track while the pupils with lower performance are oriented towards vocational training.

2 The results on aspirations that are reviewed in this section are partly extracted from Brinbaum and Kieffer (2005).

3 In this last group, the percentage of families preferring the vocational and technological tracks reaches 37 percent if both parents are low skilled.

4 The models take into account parents' social background and national origin, their level of education, the student's sex and then successively the school situation at the time of the family survey (1997-98), the child's school level evaluated by the parents.

5 In the French educational system, the baccalauréat is the last secondary school certificate (obtained by national exam). It allows pupils to enter university.

6 The 1998 questionnaire asks the respondent about his/her perception regarding the utility of the diplomas to find a job. While 28 percent of immigrant parents from a working-class origin report a strong preference for higher education programs, only 19 percent of native French families did.

7 This aspiration for longer studies in the academic track is also related to the parents' experience of unemployment and to other difficulties experienced in the labour market. 
8 The Class Council proposes an option based on the child's performance and on the wishes expressed by the family. The proposal is submitted to the family, who can accept it or appeal to a committee. In fact, the effective orientations are tightly linked with parent's expectations and demands (Duru-Bellat, 2002).

9 These models are available upon request. A separate analysis that focuses specifically on the grades in French language is available in Cebolla Boada (2006).

10 A simple test on the assumption that imposes the linear restriction that the father's and the mother's level of education are equal-sized is rejected $(F=9.68$ for mathematics; $F=7.04$ for French $(p<.01))$.

11 The argument that suggests that the mother's level of education could have a larger impact for girls than for boys could not be confirmed in this models.

12 The models presented here have also been re-run, including a more complete set of socioeconomic controls such as the number of siblings, whether the mother works outside the household, a class scheme constructed from the head of the household's occupation, sufficiency of the income available at the household level for the student to continue studying in further stages of the educational system. The results did not modify the conclusions drawn in this article.

13 Because of the low number of students that follow a technological baccalauréat, we decided to collapse this category with the general option.

14 Those outcomes are confirmed once controlled for the family social background and both parents' level of education.

15 The models on the school careers, not shown here but available upon request, show a clearly positive effect of aspirations on the careers, and especially on the orientation to the academic track.

\section{References}

Beaud, S. (2002) 80\% au bac . . . et après? Les enfants de la démocratisation scolaire ( $80 \%$ to the baccalauréat ... and after? The children of the educational democratization). Paris: La Découverte.

Beaud, S. and M. Pialoux (1999) Retour sur la condition ouvrière. Enquête aux usines Peugeot de Sochaux-Montbéliard (About the working class condition: A study in the Peugeot factories de Sochaux-Montbéliard). Paris: Fayard.

Boudon, R. (1974) Education, Opportunity, and Social Inequality: Changing Prospects in Western Society. New York : Wiley.

Boulot, S. and D. Boyzon-Fradet (1988) Les immigrés et l'école, une course d'obstacles (Immigrants at school, an obstacle race). Paris: L'Harmattan-ciemi.

Brinbaum, Y. (2002) 'Au cœur du parcours migratoire, les investissements éducatifs des familles immigrées: attentes et désillusions' (At the heart of the migration experience, the educational investments of immigrant families: Expectations and frustrations), doctoral thesis, Université Paris V.

Brinbaum, Y. and A. Kieffer (2005) 'D'une génération à l'autre, les aspirations éducatives des familles immigrées: ambition et persévérance' (From one generation to the other, the educational aspirations of immigrant families: Ambition and persistence), Education et Formations 72: 53-75. 
Brinbaum, Y. and P. Werquin (1999) 'Transition into the Labour Market of Young People from Immigrant Families: Differential Pathways', in D. Raffe, R. van der Welden and P. Werquin (eds) European Research Network on Transitions in Youth, 'Education, the Labour Market and Transitions in Youth: Cross-National Perspective', Proceedings of the 1998 European Workshop, pp. 147-64. Edinburgh: CES.

Cebolla-Boado, H. (2006) 'Ethnic Disadvantage in the Transition from Lower to Upper Secondary Education in France', Mediterranean Journal of Educational Studies 11(1): 1-29.

Clerc, P. (1964) 'Les élèves de nationalité étrangère' (Foreign nationality students), Population 19(5): 865-72.

Courgeau, D. (1973) 'Les enfants nés à l'étranger' (Children born abroad), in InedInetop (ed.) Enquête nationale sur le niveau intellectuel des enfants d'âge scolaire, Travaux et Documents, cahier no. 64. Paris: PUF.

Duru-Bellat, M. (2002) Les inégalités sociales à l'école. Genèse et mythes (Social inequalities at school: Origin and myths). Paris: PUF.

Duru-Bellat, M. and A. Kieffer (2000) 'La démocratisation de l'enseignement en France: polémiques autour d'une question d'actualité' (The democratization of education in France: Debates around a current question), Population 55(1): 51-80.

Duru-Bellat, M. and A. Mingat (1990) 'How do French Junior Secondary Schools Operate? Academic Achievement, Grading and Streaming of Students', in A. Leschinsky and K.U. Mayer (eds) The Comprehensive School Experiment Revisited: Evidence from Western Europe, pp. 275-305. Frankfurt: Peter Lang.

Duru-Bellat, M., J.-P Jarousse and A. Mingat (1993) 'Les scolarités de la maternelle au lycée. Étapes et processus dans la production des inégalités sociales' (Schooling from preschool to the lycée: Stages and processes in the production of social inequalities), Revue française de Sociologie 34.

Felouzis, G. (2003) 'La ségrégation ethnique au collège et ses conséquences' (Ethnic segregation at school and its consequences), Revue française de sociologie 44(3): 413-47.

Gratiot Alphandéry, H. and B. Lambiot (1973) Le retard scolaire des enfants de travailleurs immigrés en France' (The school disadvantage of the children of immigrant workers in France), unpublished report, Centre international de l'enfance, Paris.

INSEE (1990) Recensement de la population (Population census). France: INSEE. INSEE (1999) Recensement de la population (Population census). France: INSEE.

Kao, G. and M. Tienda (1995) 'Optimism and Achievement: The Educational Performance of Immigrant Youth', Social Science Quarterly 76(1): 1-19.

Mallet, P. and S. Bousta (1988) Jeunesses immigrées et société française (Immigrant youth and French society), MIRE report. Paris: Ecole Pratique des Hautes Etudes.

Merle, P. (2002) 'Démocratisation ou accroissement des inégalités scolaires? L'exemple de l'évolution de la durée des études en France (1988-1998)' (Democratization or reduction of school inequalities? The example of the evolution of the length of schooling in France (1988-1998)), Population 57(4-5): 633-60. 
Ministère de l'Éducation National (1995) 'Panel d'Élèves du Sécond Degré', Ministère de l'Éducation National, France.

Mondon, P. (1984) 'Quelques aspects de la scolarisation des enfants étrangers à partir des statistiques' (Some aspects of the schooling experience of the foreign children using statistics), Migrants-Formation 58: 6-14.

Noiriel, G. (1988) Le creuset français. Histoire de l'immigration (The French melting pot: The history of immigration). Paris: Le Seuil.

Ogbu, J.U. (1978) Minority Education and Caste: The American System in CrossCultural Perspective. New York: Academic Press.

SEIS (1980) 'Comparaison des cursus des élèves étrangers et des élèves français. Regroupement des trois échantillons de suivi d'élèves', (A comparison of the school careers of foreign and French students), Working document 223, Ministère de l'Education Nationale, France.

SIGES (1984) 'Les élèves étrangers dans le panel 1978 premier degré' (Foreign students in the 1978 first-stage panel), Working document 309, Ministère de l'Education Nationale, France.

Thélot, C. and L.-A. Vallet, (1994) 'Compétences en français et carrières scolaires des élèves étrangers en France' (Competence in French and school careers among foreign born students in France), in Actes du Séminaire sur les indicateurs d'intégration des immigrants, pp. 179-206. Montreal: Université de Montréal et Gouvernement du Québec,

Thin, D. (1998) Quartiers populaires. L'école et les familles (Popular neighbourhoods: Schools and families). Lyon: PUL.

Tribalat, M. (1995) Faire France: Une enquête sur les immigres et leurs enfants (Making France: A study of immigrants and their children). Paris: La Découverte.

Tribalat, M. (2004) 'Une estimation des populations d'origine étrangère en France en 1999' (An estimation of the foreign-origin populations in France in 1999), Population 59: 51-82.

Vallet, L.-A. and J.-P. Caille (1996) 'Les élèves étrangers ou issus de l'immigration dans l'école et le collège français. Une étude d'ensemble' (The foreign and immigrant origin students in the primary and lower secondary French school: A comprehensive study), Les dossiers d'Education et Formations 67, Ministère de l'Éducation National, France.

Van Zanten, A. (2001) L'école de la périphérie. Scolarité et ségrégation en banlieue (The school of the periphery. Schooling and segregation in the suburbs). Paris: PUF.

Zéroulou, Z. (1988) 'La réussite scolaire des enfants d'immigrés: l'apport d'une approche en termes de mobilisation' (The school success of the children of immigrants: a mobilization approach), Revue française de sociologie 29(3): $447-70$. 
YAËL BRINBAUM is a Sociologist, and Assistant-Professor at the University of Burgundy, Researcher at the Institute of Research in Education (IREDU, CNRS) in Dijon and at the Maurice Halbwachs Center in Paris. Address: IREDU - Université de Bourgogne Pole AAFE BP 2651321065 Dijon Cedex, France. [email: yael.brinbaum@ens.fr]

HECTOR CEBOLLA-BOADO is a PhD candidate at Nuffield College, University of Oxford and CEACS-Juan March Institute, and a full-time researcher at the UNED. Address: Departmento de Sociología II, Obispo Trejo s/n. 28040 Madrid, Spain. [email: hcebolla@ceacs.march.es]

\section{APPENDIX}

\section{Data and categories}

The 1995 National Longitudinal Study of the French Ministry of Education (Ministère de l'Éducation Nationale, 1995) surveyed a cohort of 17,830 students entering into lower secondary school (collège) in 1995. Although attrition is indeed an important problem, the panel covers a representative sub-sample of students until the end of upper secondary schooling. As well as a recruitment questionnaire completed in 1995 with some retrospective information about the students' prior education and family background, two important sets of interviews were conducted in 1998 and 2002.

The 1998 family questionnaire draws information about migration as well as parental expectations regarding the student's careers. The 2002 youth questionnaire was used to interview the students retrospectively about their school experience and their future plans. ${ }^{1}$

These longitudinal data make it possible, for the first time, to analyse the links between parents' trajectories, resources, educational aspirations, and the effective school careers of their children. This database contains information on the school performances (such as mark at the brevet des collèges) and on the representations of the child's level, evaluated at this time by parents (in 1998). Table A1 shows the sample size in each year and the rate of answers obtained.

\section{Immigration categories}

This survey permits the identification of immigrant populations, using information about the parents' place of birth. An immigrant is defined as a foreigner or French citizen by naturalization that was born in a foreign country. A first-generation immigrant student is the foreign-born child of a 
Table A1 Sample size in the French panel of students

\begin{tabular}{lcc}
\hline Name of the questionnaire & $N$ & Rate of answers (\%) \\
\hline Recruitment questionnaire 1995 & 17,830 & 100 \\
Questionnaire end of 3ème (1999, 2000 or 2001) & 15,159 & 85 \\
Family questionnaire 1998 (first part) & 15,290 & 85.7 \\
Family questionnaire 1998 (postal) & 12,981 & 72.8 \\
\hline
\end{tabular}

a This questionnaire was only collected for the students in 3ème. Logically, if the student repeated any year, the questionnaire was not completed with the rest of the cohort, but only when he or she reached 3ème.

foreign-born parental couple while a second-generation immigrant student is the French-born child of immigrant parents.

Our immigration groups also distinguish between the children of two immigrant parents and the children of mixed parental couples. Ethnic differentials are measured distinguishing the Portuguese and the North Africans (Algerians, Moroccans and Tunisians) - the most numerous groups in France - from other nationalities. ${ }^{2}$

\section{Variables of social background}

An indicator was built to approximate the social milieu of the student's family (Table A2). This was based on the occupations of both parents and their level of skills: lower category (blue or white collar workers); intermediate category (farmers, self-employed, shop-keepers etc.) and upper category (upper profession, employers). ${ }^{3}$ The majority of immigrants belong to the lower categories, including skilled and unskilled workers (between $70 \%$ and $90 \%$ ). It is for this reason that we focus on the lower category, in order to compare immigrant with native French families that belong to the same social milieu. The whole population is taken into account in the models, in order to test the detailed effect of social origin.

\section{Notes}

1 The field of study is concerned with young people respondents in 2002, and their parents who participated in the family survey in 1998. The sample is then composed of 9976 families. Then, we use the weightings.

2 We did not distinguish more ethnic groups because of the sample size. The children of repatriates (the native French from the Algeria colony) are not in the sample of the children of North Africans.

3 At the detailed level, we distinguish if one or both parents belong to each category (if both, they are in homogeneous categories, if not in heterogeneous one. We also distinguish the skilled or unskilled blue or white collar workers. Those two last groups constitute the lower categories. 


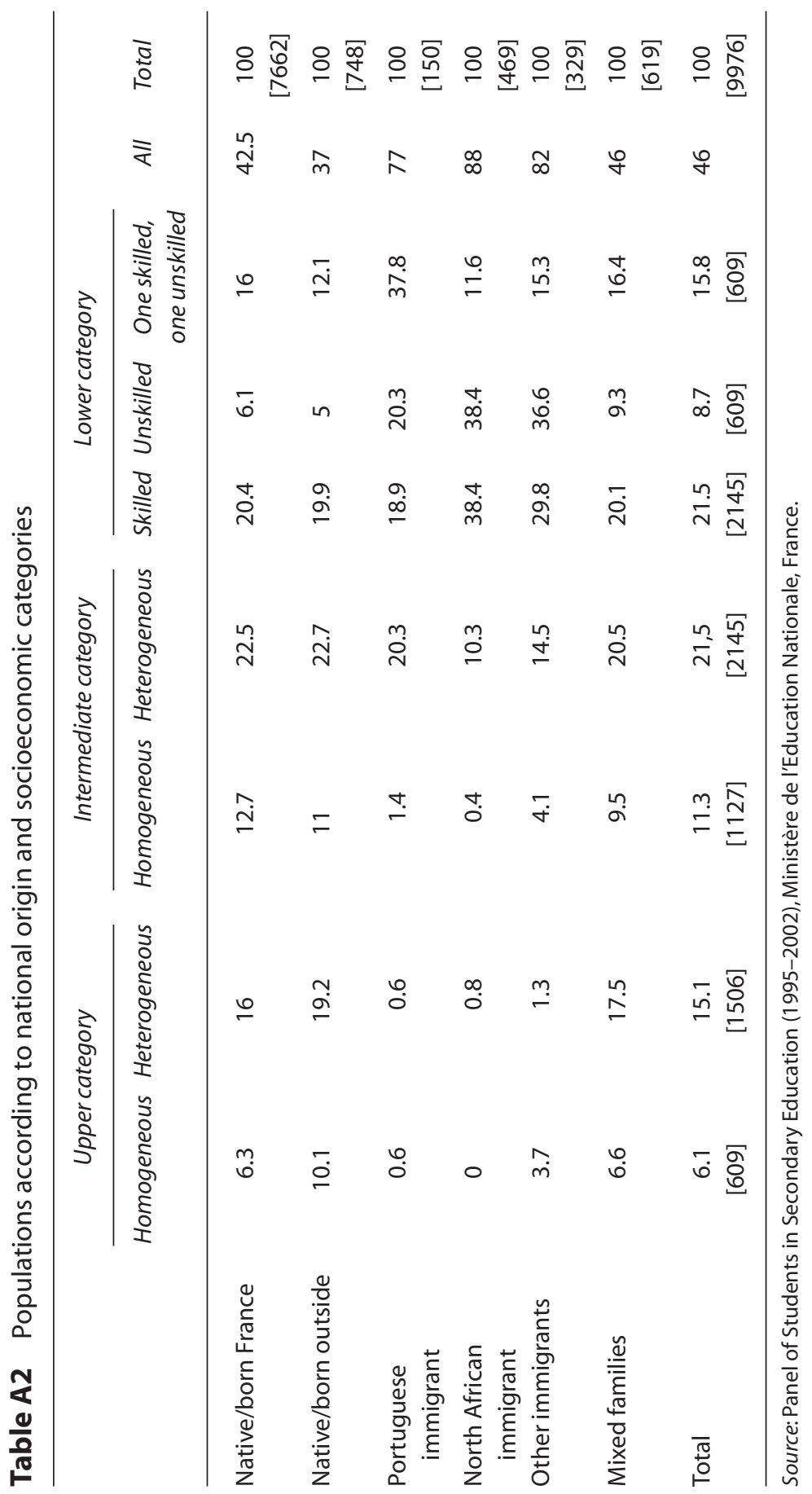









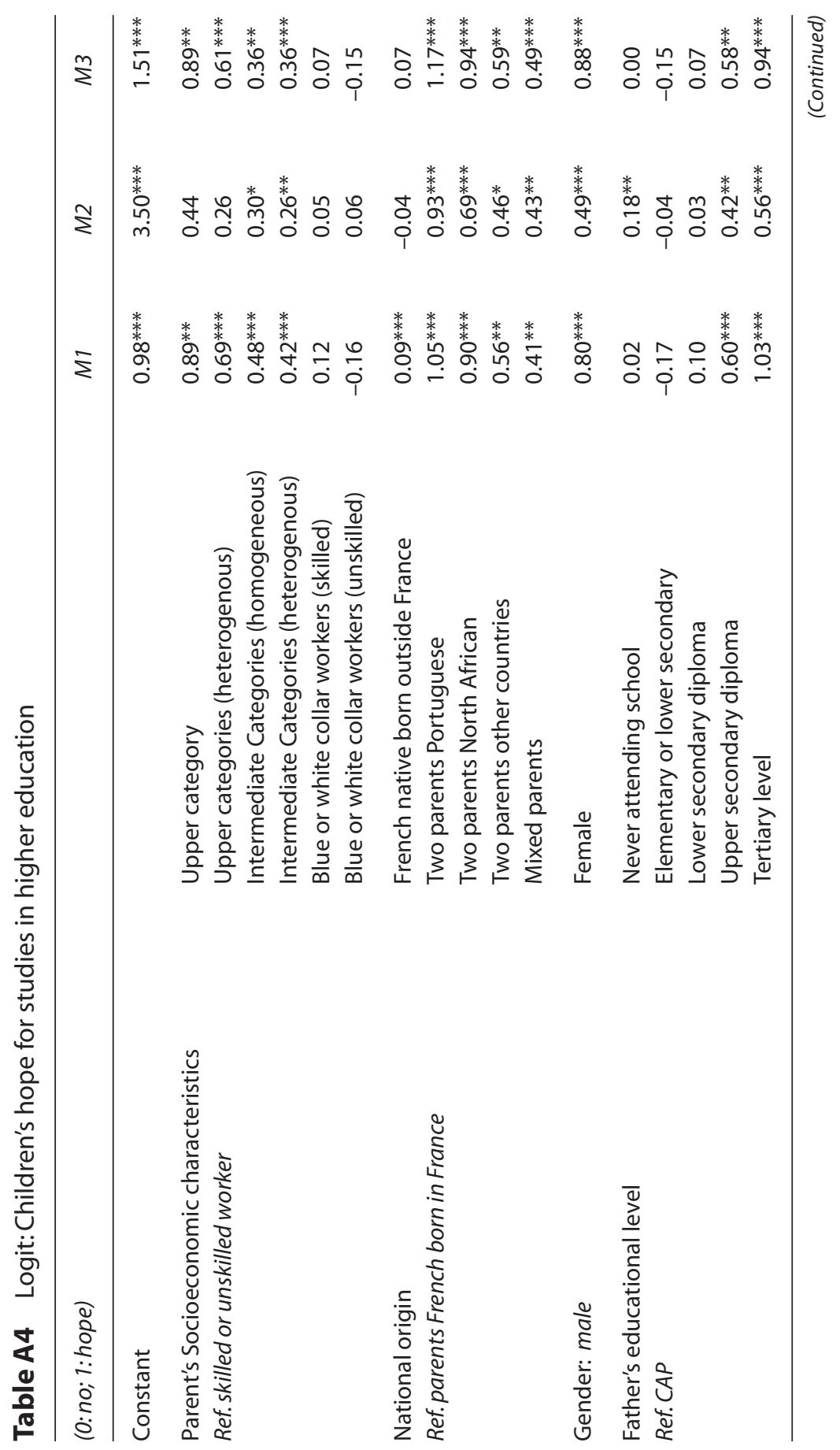




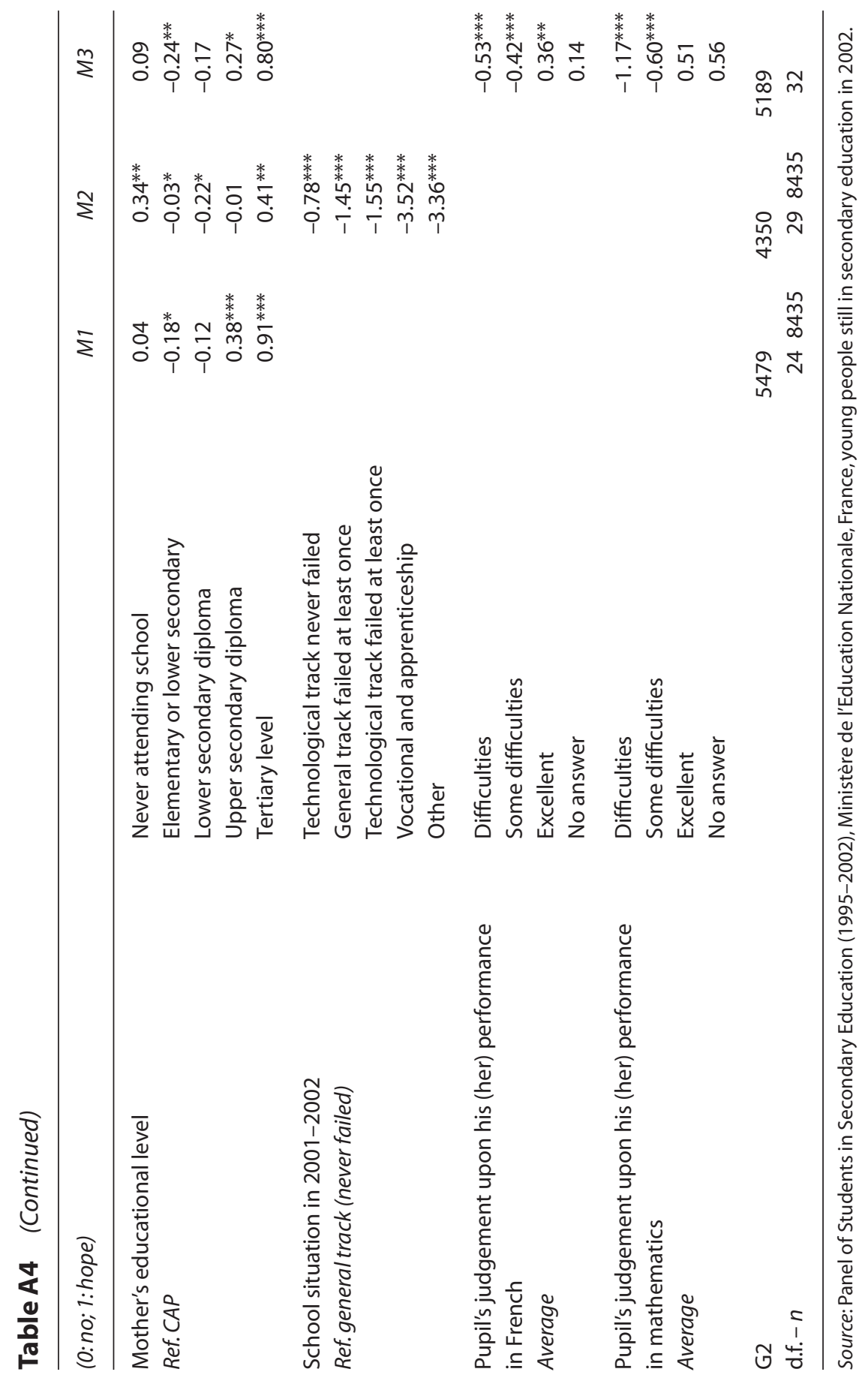

